\title{
1
}

\section{Introduction: Understanding the Challenges of the Agricultural Sector in Sub-Saharan Africa}

\section{Abebe Shimeles, Audrey Verdier-Chouchane, and Amadou Boly}

\subsection{Introduction}

Sub-Saharan African countries have recorded relatively high economic growth over the past two decades, but this growth has largely been jobless and poverty and inequality are still widespread (African Development Bank et al. 2017). Also, Africa's growth has hardly been accompanied by structural transformation. The labor force is still stuck in subsistence production and low productive agricultural sector which employs more than half of the sub-Saharan population. According to the International Labour Organization (2017), the agricultural sector employs an average of $54 \%$ of the working population in Africa. In Burundi, Burkina Faso and Madagascar, more than $80 \%$ of the labor force works in agriculture. By contrast, in Angola, South Africa, and Mauritius, the agricultural sector only employs $5.1 \%, 4.6 \%$, and $7.8 \%$ of the population, respectively.

A. Shimeles $\bullet$ A. Verdier-Chouchane $(\bowtie) \bullet$ A. Boly African Development Bank, Abidjan, Côte d'Ivoire 
In addition to the massive labor force, sub-Saharan Africa has also the highest area of arable uncultivated land in the world and huge agricultural growth potential (Kanu et al. 2014). But countries have not yet taken advantage of it. Despite the importance of the sector, about one-fourth of the population experiences hunger in sub-Saharan Africa. Out of about 795 million people suffering from chronic undernourishment globally, 220 million live in sub-Saharan Africa. At around 23.2\%, the Food and Agricultural Organization (FAO) (2015) indicates that this is the highest prevalence of undernourishment worldwide. Even in abundant regions, food shortages can happen, mostly due to poor conservation techniques or post-harvest losses. In fact, the continent overall is a net importer of food which puts additional strain on scarce foreign exchange reserves.

In agriculture, women face particularly severe challenges. Although they represent $47 \%$ of the labor force, they are prominently smallholder farmers because the patriarchy system has tended to discriminate against them (Kanu et al. 2014). Customary laws and rules governing ownership and transfer of land rights are generally unfavorable to women in subSaharan Africa, conferring title and inheritance rights upon male family members. For Woldemichael et al. (2017), women in agriculture also experience lack of access to finance, modern inputs as well as lack of knowledge and skills of modern agricultural practices. Without these disadvantages as compared to males, women could be as industrious as men, not only in agriculture but also in every sector. As per the FAO (2011), if women had access to the same resources as men, their agricultural yields would increase by up to 30\%, reducing by 100-150 million the number of hungry people globally.

For Moyo et al. (2015), Africa's low use of irrigation and overwhelming dependence on rain-fed agriculture explain the continent's low agricultural productivity. The main staples of sub-Saharan Africa are unirrigated crops (maize, cassava, millets, sorghum, yams, sweet potatoes, plantains and rice). In addition, limited public funding in the agricultural sector has also prevented the provision of adequate institutional support and suitable business environment, in turn hindering private sector participation and investment in agriculture. Under the terms of 
the New Partnership for Africa's Development's (NEPAD) Comprehensive Africa Agriculture Development Programme (CAADP), ${ }^{1}$ governments should devote $10 \%$ of national spending to agriculture in order to support water management, intensify irrigation, reduce the continent's dependence on rain-fed agriculture and increase resilience to climate change. However, Fig. 1.1 clearly indicates that public expenditure in agriculture is far below the $10 \%$ target, ranging from a low $0.15 \%$ in Guinea-Bissau to $3.61 \%$ in Malawi.

This low level of investment prevents countries from adapting to climate change shocks, limited rainfall and weather shocks. For Kanu et al. (2014), climate change poses a great challenge to promoting inclusive growth in sub-Saharan Africa. Due to climate disturbances, growing and harvesting seasons are increasingly unpredictable. In addition, the region has one of the most vulnerable agriculture worldwide to extreme weather events, such as drought and floods due to its heavy reliance on rain-fed agriculture, low adaptive capacity and limited infrastructure development.

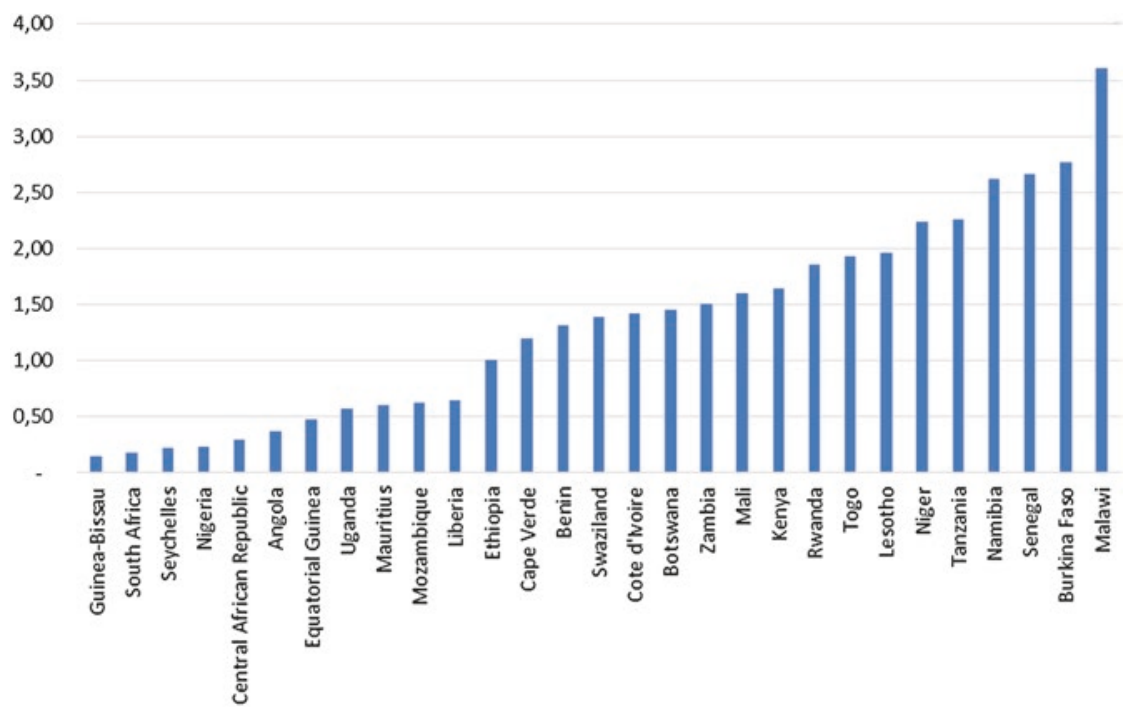

Fig. 1.1 Percentage of agricultural expenditure in total GDP. Source: Authors, based on IFPRI (2017). Note: more recent year between 2009 and 2012 
Increasing agricultural productivity would support structural transformation process and economic growth in sub-Saharan Africa for three reasons. First, it will enable the labor force to move from the agricultural sector into other sectors and help developing the manufacturing and services sector. There is a high momentum behind developing and promoting the agricultural sector as a catalyst to industrialization and agribusiness development. Second, it will allow African farmers to better manage and integrate the entire agricultural value chain from the farm to storage, transport, processing, marketing and distribution. This will not only improve food supply but also create additional revenues and jobs. Third, farmers will be able take advantage of large markets, increase trade and exports of agricultural products and progressively integrate regional and global value chains (GVCs). ${ }^{2}$ However, farmers need to deliver high-quality products at competitive prices and integrate international distribution channels by satisfying the norms and standards set out by their trading partners (AfDB 2014).

This volume on Building a Resilient and Sustainable Agriculture in SubSaharan Africa presents 13 chapters related to a better understanding of agriculture in sub-Saharan Africa and to the best policy options for enhancing its resilience and sustainability. In Part I, the authors looked into the issues of productivity, sometimes by gender, with a specific focus on modern inputs, including machinery, fertilizers and improved seed varieties. They also demonstrate that some crop adoption can reduce farmers' income if not adequately planned or completed with other measures. In Part II, the authors analyzed the climate change challenges in agriculture and its vulnerability to drought and declining soil fertility. Authors deal with soil and water conservation techniques, land tenure issues and weather index insurance. In Part III, authors considered the promotion of agro-industrialization. They review the contribution of agricultural activities to the development of the manufacturing sector, focus on the creation of special economic zones (SEZs) to transform agriculture and examine Economic Community of West African States' (ECOWAS) integration in GVCs. The remaining of this overview chapter gives a flavor of the main issues discussed. It follows the outline of the entire volume. 


\subsection{Improving Agricultural Productivity}

In sub-Saharan Africa, agricultural sector productivity considerably lags other regions (see Fig. 1.2). According to NEPAD (2013), Africa has 33 million farms of less than 2 hectares, accounting for $80 \%$ of all farms. Given that the farming system mainly relies on family's capital and labor force for production, the overall productivity is low. Subsistence farmers cannot significantly contribute to food security at a national scale because the pieces of land they have access to are too small (Africa Research Institute 2009).

In Chap. 2, Christelle Tchamou Meughoyi analyzes whether improved maize seeds can significantly increase the productivity of family farms in Cameroon. Considering 259 family farms, she uses the Blinder-Oaxaca decomposition technique to estimate the difference in productivity between the adopters and non-adopters of improved seeds. She concludes that yield obtained by adopters is 1.42 times higher than

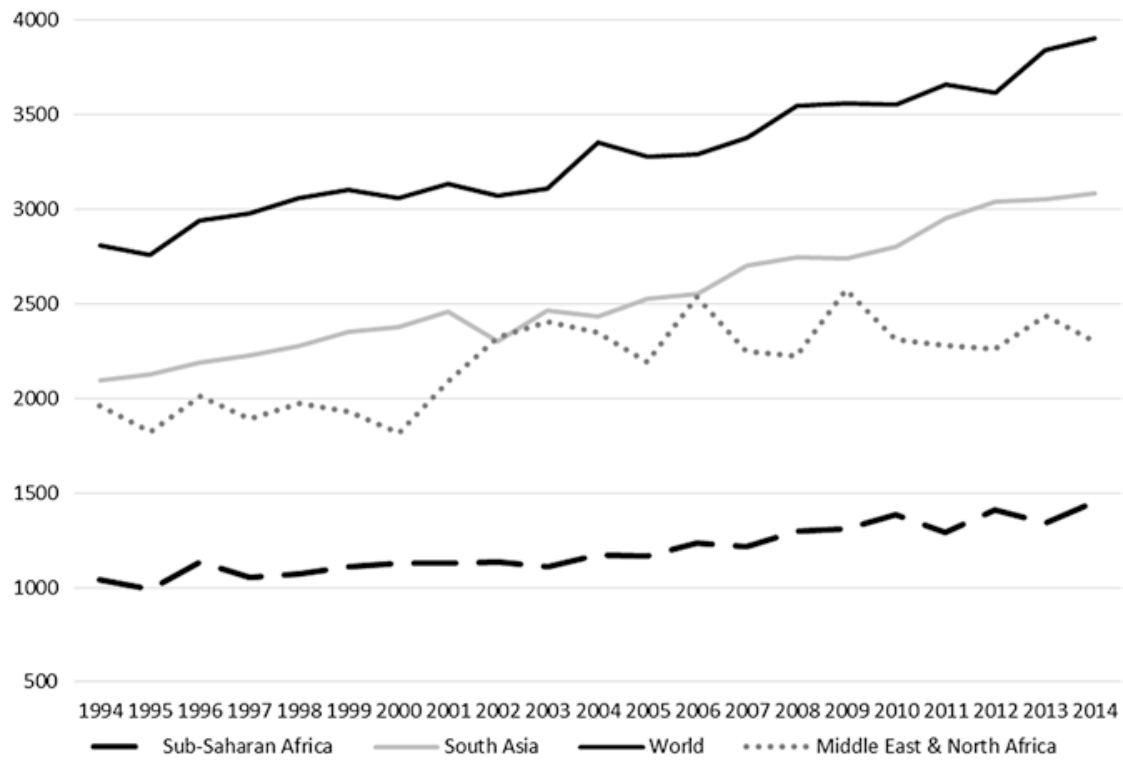

Fig. 1.2 Cereal yield (kilogram per hectare). Source: Authors based on data from the World Bank (online) World Development Indicators 
the one obtained by the non-adopters. However, this is far below the expected theoretical productivity gap. Farmers may fail to comply with the conditions associated with improved seed varieties, including the use, method and period of application of fertilizers, herbicides and weeding. She highlights the fact that such innovations should be combined with other modern inputs to have the expected result. Ripple effect of improved seed varieties on other factors of production entail additional cost for the farmers and should be taken into account.

However, the modernization of agriculture is a priority for increasing productivity and moving away from subsistence agriculture. In Chap. 3, Carren Pindiriri examines the drivers of agricultural technology adoption by smallholder farmers in Zimbabwe. Using a sample of 411 farmers in Hurungwe, she finds a population technological gap of $12.7 \%$ resulting from lack of awareness. Farmers' propensity to adopt modern technologies increases with education, training, access to credit and income. She then highlights the need to reduce technology information asymmetry among farmers through various media and to improve financial services in rural areas.

In Chap. 4, Adedoyin Mistura Rufai, Kabir Kayode Salman and Mutiat Bukola Salawu explore the influences of input utilization on labor productivity among men and women in Nigeria using the General Household Survey and a quantile regression method. The use of modern inputs, such as fertilizer, herbicide, pesticide, animal traction and machinery equipment, is generally low in Nigeria's agriculture. However, women, who constitute about half of the labor force in the agricultural sector, face lower access than men. As a result, it contributes to gender productivity differentials and ineffective use of the vast human resources available. The authors conclude that productivity of the agricultural sector in Nigeria can be improved extensively through gender-sensitive policy and capacity building of female farmers.

In Chap. 5, O. E. Ayinde, T. Abdoulaye, G. A. Olaoye and A. O. Oloyede also consider the role of women in Nigeria's agriculture with the objective of increasing their involvement in on-farm trails of agricultural technologies. Authors interviewed about 80 female farmers who have adopted improved seeds (drought-tolerant (DT) maize varieties). 
The women's varietal preference and the profitability of the maize varieties differ across locations. However, the women farmers ranked the DT maize variety as the best, having the highest profit and returns to investment at all the locations. The authors reaffirm the specific role of women in ensuring food security and increasing agricultural productivity. They recommend their strong involvement in the development and testing of agricultural innovation, especially in a context of climate change.

In Chap. 6, Lauretta S. Kemeze, Akwasi Mensah-Bonsu, Irene S. Egyir, D. P. K. Amegashie and Jean Hugues Nlom focus on the impact of the Jatropha curcas adoption on farmers' incomes in Northern Ghana. In the mid-2000s, this bioenergy cultivation was presented as a panacea and a promising feedstock for biofuels. However, large-scale Jatropha (100 hectares and more) development was criticized for land grabbing and food insecurity. In addition, using data from 400 farmers and a Propensity Score Matching method, the authors found that the adoption of Jatropha curcas significantly reduces farmers' total crop incomes per hectare. The gender analysis also reveals that this reduction was more important for female-headed households. The authors recommend the protection of rural people and food crops and insist in the necessity of adopting a proper regulation of the biofuel sector in Ghana.

\subsection{Addressing Climate Change Challenges}

A key challenge for sub-Saharan African countries is to reverse costly environment degradation and better adapt to climate change shocks. AfDB (2011) estimated that an investment of USD 20-30 billion annually would be required to reduce climate vulnerability in Africa and to maintain the potential negative effect at $1.8 \%$ of Africa's GDP. However, sometimes there is a trade-off between protecting the environment and enhancing agricultural productivity (Verdier-Chouchane \& Karagueuzian 2016).

In Chap. 7, Idrissa Ouiminga proposes solutions to combat land degradation and desertification. Repeated droughts and inadequate practices in agriculture have resulted in the decline of soil fertility and the 
degradation of the vegetation cover. Considering different soil and water conservation techniques, the author examines both financial profitability, yields and social impact (labor) through a cost-benefit analysis in the municipality of Yalgo, Burkina Faso. Soil conservation techniques range from mulching, compost, manure and fertilizer such as NPK (Nitrogen, Phosphorous and Potassium), while water conservation techniques include dugs and constructed structures such as stony ropes, half-moons and water cuvettes. These techniques, usually supported by public investment, represent a good alternative to adapting to climate change.

In Chap. 8, Boris Odilon Kounagbè Lokonon analyzes the vulnerability of villages to climate shocks and the extent to which land tenure has affected vulnerability in Benin. Using data over 1998-2012, the author calculates indices for each dimension of vulnerability (adaptive capacity, sensitivity and exposure) and then overall vulnerability indices. Generally, the situation has improved over the period but the adaptive capacity is very low, questioning the villages' resilience on future climate shocks. The econometric analysis reveals that farmers' labor sharing and organizations have the potential to lessen vulnerability to climate shocks. In contrast, land tenure is not significant in strengthening resilience. It is considered as a social protection measure that could increase productivity should it be accompanied by appropriate financial capital and access to technology.

In Chap. 9, Francis H. Kemeze looks at the weather index insurance which partially protects farmers against climate variability and partially compensates for the negative effects of drought. Specifically, the author looks into the effects of drought index insurance on the demand for supplemental irrigation in Northern Ghana. Weather insurance does not usually cover actual on-farm losses and does not replace the crop loss. In addition, in case of drought, price of staple food goes up and prevents farmers from smoothing their consumption with the insurance premium. The result of the randomized control trials (RCT) analysis confirms that index insurance covers the costs of irrigations in drought years. As a result, farmers should apply additional water to otherwise rain-fed crops to save the harvest. The investment in water management is complementary drought adaptation strategy. 


\subsection{Promoting Agro-Industrialization}

The connection of small-scale farmers to large business farmers through mutually beneficial contract farming (also called out-grower schemes) facilitates famers' access to inputs, financing, end-markets as well as their participation in agriculture value chains. However, for Verdier-Chouchane \& Karagueuzian 2016, a comprehensive transformation of the agricultural sector in Africa toward agro-industrialization requires investments in technology and innovation in order to improve the productivity of both land and labor. An example of the use of Internet to improve integration into value chains is the traceability of food and animals which entails displaying the lot number and the production facility name on each case of the product and recording this information on invoices and bills of lading (VerdierChouchane \& Boly 2017). Innovation can also facilitate commercialization and enhance farmers' access to broader markets and financial systems. For Moyo et al. (2015), this will ultimately allow the creation of modern integrated agribusiness value chain economies based on specialization. Domestic and international private investment in the agricultural sector has already caused remarkable changes in agribusiness in Africa with positive effects on smallholder farmers' revenues and productivity (Kanu et al. 2014).

In Chap. 10, Namalguebzanga C. Kafando considers Africa's z advantage in agricultural products and its industrialization based on the exploitation of natural resources. The author confirms that their processing can enhance the value added of exports and Africa's industrial development, especially in West and Central Africa where the value added of the manufacturing sector is very low. However, the author also reviews the obstacles toward industrial and regional value chains development in Africa and recommends some policy actions. He mainly focuses on the role of education and skills, transport infrastructure, governance quality, trade integration and the use of technology.

In Chap. 11, Joseph Tinarwo focuses on the role that SEZs can play in transforming Africa's agriculture and developing agribusiness markets. In SEZs, economic regulations are different from those of the rest of the country. By mainstreaming the administration, providing tax incentives and low tariffs, SEZs improve the business environment and facilitate the access to new markets and encourage the concentration of industrial 
growth. Basing his analysis on experiences in Asia and Africa, the author provides recommendations to ensure a successful agricultural transformation in Africa through SEZ development. He also highlights the need for further research and additional empirical data.

Finally, in Chap. 12, Anani N. Mensah and Abdul-Fahd Fofana examine the level of integration and the upgrading of ECOWAS member countries in the GVCs. Using indicators of product sophistication and diversification, the authors find that the agricultural products ECOWAS countries export abroad are mainly primary low-tech products. Trade is strongly driven by forward integration as primary products are transformed and used for manufacturing outside ECOWAS. In contrast, countries should develop backward integration by improving competitiveness', supporting export companies and investing in infrastructure.

\section{Notes}

1. http://www.nepad.org/cop/comprehensive-africa-agriculturedevelopment-programme-caadp.

2. For Gereffi and Fernandez-Stark (2011), the global value chain is the interconnected production process that goods and services undergo from conception and design through production, marketing and distribution. Country's participation in GVC trade is measured by both the backward and forward integration. Backward integration occurs when a country sources foreign inputs for its export production, while forward integration occurs when a country provides inputs for a foreign country's export production.

\section{References}

AfDB. (2014). Global Value Chains and Africa's Integration into the Global Economy. Annual Report 2013, Chapter 2. Tunis: AfDB.

AfDB, Organisation for Economic Co-operation and Development [OECD], \& United Nations Development Programme [UNDP]. (2017). African Economic Outlook 2017. Paris: OECD Publishing. Retrieved from http:// www.africaneconomicoutlook.org/en/. 
Africa Research Institute. (2009, November). Waiting for a Green Revolution. Briefing Note 0902.

African Development Bank [AfDB]. (2011). The Cost of Adaptation to Climate Change in Africa. Tunis: African Development Bank.

FAO. (2015). The State of Food Insecurity in the World. Rome: FAO.

Food and Agricultural Organization of the United Nations [FAO]. (2011). The State of Food and Agriculture 2010-2011: Women in Agriculture. Closing the Gender Gap for Development. Rome: FAO.

Gereffi, G., \& Fernandez-Stark, K. (2011). Global Value Chain Analysis: A Primer. Durham, NC: Center of Globalization, Governance and Competitiveness.

IFPRI. (2017). SPEED Dataset 2015. Washington: IFPRI.

International Labor Organization [ILO]. (2017). Foresight Africa 2017 Report. Geneva: ILO.

Kanu, B. S., Salami, A. O., \& Numasawa, K. (2014). Inclusive Growth: An Imperative for African Agriculture. Tunis: African Development Bank.

Moyo, J. M., Bah, E. M., \& Verdier-Chouchane, A. (2015). Transforming Africa's Agriculture to Improve Competitiveness. World Economic Forum, World Bank and AfDB (2015). Africa Competitiveness Report 2015. Geneva: WEF.

NEPAD. (2013). Agriculture and Africa-Transformation and Outlook. Johannesburg: NEPAD.

Verdier-Chouchane, A., \& Boly, A. (2017). Introduction: Challenges to Africa's Agricultural Transformation. African Development Review, 29(S2), 75-77.

Verdier-Chouchane, A., \& Karagueuzian, C. (2016). Moving Towards a Green Productive Agriculture in Africa: The Role of ICTs. Africa Economic Brief, 7(7). Côte d'Ivoire: African Development Bank.

Woldemichael, A., Salami, A., Mukasa, A., Simpasa, A., \& Shimeles, A. (2017). Transforming Africa's Agriculture Through Agro-Industrialization. Africa Economic Brief, 8(7), Abidjan: African Development Bank. 
Open Access This chapter is licensed under the terms of the Creative Commons Attribution 4.0 International License (http://creativecommons.org/licenses/ by/4.0/), which permits use, sharing, adaptation, distribution and reproduction in any medium or format, as long as you give appropriate credit to the original author(s) and the source, provide a link to the Creative Commons license and indicate if changes were made.

The images or other third party material in this chapter are included in the chapter's Creative Commons license, unless indicated otherwise in a credit line to the material. If material is not included in the chapter's Creative Commons license and your intended use is not permitted by statutory regulation or exceeds the permitted use, you will need to obtain permission directly from the copyright holder.

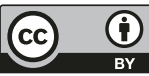

